\title{
Psychological Well-Being ditinjau dari Mindfulness Pada Atlet Remaja Difabel di NPC Prov Sumut
}

\section{Psychological Well-Being reviewed from Mindfulness In Adolescents Disability in NPC Province North Sumatera}

\author{
Yemima Patricia Tumanggor(1*), Rolando Aritonang(2), Annisa Sera Nabila(3), Nikita \\ Alvionita(4) \& Winida Marpaung(5) $^{(4)}$ \\ Fakultas Psikologi, Universitas Prima Indonesia, Indonesia
}

Disubmit: 14 Januari 2021; Diproses: 29 Januari 2021; Diaccept: 16 Maret 2021; Dipublish: 02 Agustus 2021

*Corresponding author: E-mail: yemimapatriciatmg@gmail.com

\begin{abstract}
Abstrak
Penelitian ini bertujuan untuk mengetahui hubungan antara mindfulness dengan psychological well- being pada atlet remaja difabel di National Paralympic Committee Provinsi Sumatera Utara. Hipotesis penelitian ini adalah terdapat hubungan antara mindfulness dengan psychological well-being. Sampel yang diambil untuk penelitian ini berjumlah 100 orang. Metode yang digunakan adalah metode kuantitatif, data dikumpulkan menggunakan skala mindfulness dengan butir 40 aitem dan skala psychological well-being dengan 36 butir aitem. Uji asumsi yang digunakan yaitu uji normalitas dan uji linearitas. Data analisis menggunakan uji korelasi Pearson Product Moment. Hasil analisis data menunjukkan adanya hubungan antara mindfulness dengan psychological well-being dengan koefisien korelasi Pearson Product Moment sebesar $\mathrm{R}=0.278$ dengan sig 0.005 (p $<0.05$ ). Hasil penelitian ini menunjukkan bahwa sumbangan yang diberikan variabel mindfulness terhadap psychological well-being sebesar 0.77\%, selebihnya 99.23\% dipengaruhi oleh faktor lain yang tidak diteliti. Dari hasil penelitian ini dapat disimpulkan bahwa hipotesis penelitian dapat diterima.
\end{abstract}

Kata Kunci: Psychological well-being; Mindfulness; Remaja

\begin{abstract}
This study aims to determine the relation between mindfulness and psychological well-being in adolescent athletes with disabilities in the National Paralympic Committee of North Sumatra Province. The hypothesis in this study is that there is a relationship between mindfulness and psychological well-being. The sample taken for this study amounted to 100 people. This research uses quantitative methods, data were collected using a mindfulness scale with 40 items and a psychological well-being scale with 36 items. The assumption test used consists of a normality test and a linearity test. The data were analyzed using the Pearson Product Moment correlation test. The results of data analysis showed a positive correlation between mindfulness and psychological well-being with a Pearson Product Moment correlation coefficient of $R=0.278$ with sig $0.005(p<0.05)$. The results of this study indicate that the contribution given by the mindfulness variable to psychological well-being is $0.77 \%$, while the remaining $99.23 \%$ is influenced by other factors not examined. From the results of this study it can be concluded that the research hypothesis is acceptable.
\end{abstract}

Keywords: Mindfulness; Psychological well being; Adolescent

DOI: https://doi.org/10.51849/j-p3k.v2i1.86

Rekomendasi mensitasi :

Tumanggor, Y.P, Aritonang, R., Nabila, A.S, Alvionita, N., Marpaung, W. (2021). Psychological Well-Being ditinjau dari Mindfulness Pada Atlet Remaja Difabel. Jurnal Penelitian Pendidikan, Psikologi dan Kesehatan (J-P3K), 2 (2): 102-106. 


\section{PENDAHULUAN}

Dalam masa perkembangannya, manusia melewati beberapa fase mulai dari masa kanak-kanak, remaja, dewasa, hingga lanjut usia. Salah satu fase perkembangan yang terpenting dan berkaitan dengan masa produktif ialah masa remaja.

Papalia, Olds dan Feldman (dalam Jahja, 2012) mengungkapkan masa remaja sebagai masa transisi yang dialami pada masa kanak-kanak dan dewasa yang terjadi pada usia 11-20 tahun. Hurlock (dalam Jahja, 2012) menyatakan bahwa dalam masa remaja, terjadi perubahan baik secara psikologis, kehidupan sosial, serta fisik. Sayangnya, sebagian dari remaja mengalami kesulitan karena keterbatasan fisik yang dialaminya.

Ketidaksempurnaan fisik menjadi penghambat dalam menjalankan aktifitas dan kehidupan secara normal. Dari kondisi tersebut, tak jarang para difabel mengalami dampak negatif disabilitas. Nanda Mei Sholihah, seorang atlet difabel yang berprestasi juga pernah merasa didiskriminasi lingkungan sekitar karena kondisi fisiknya, ia mengalami penolakan untuk bersekolah karena sekolah tidak bisa menerima anak berkebutuhan khusus.

Senra, Oliveira, Leaf, dan Vieira (2011) mengemukakan ada beberapa dampak negatif dari disabilitas fisik seperti depresi, trauma, marah, shock, tidak menerima kenyataan dan bunuh diri. Hal ini akhirnya mempengaruhi emosi individu menjadi tidak bahagia dan berdampak bagi kesejahteraan psikologis. Psychological well-being menurut Ryff dan Keyes (1995) adalah kondisi seseorang yang bebas bukan hanya dari tekanan atau masalah mental namun juga kondisi mental yang dianggap sehat dan berfungsi maksimal.

Ryff (1995) mengatakan bahwa psychological well-being adalah pencapaian secara penuh dari psikologis seseorang dan keadaaan di mana individu menerima apa adanya kekuatan dan kelemahan diri, adanya tujuan hidup, kemampuan mengembangkan relasi positif, mandiri, mengendalikan lingkungan serta terus bertumbuh (dalam Tasema, 2018).

Psychological well-being berarti melibatkan proses internal dan eksternal seseorang, salah satunya ialah mindfulness yang memperkuat atensi. Kabat-Zinn (1994) menyatakan bahwa mindfulness membantu seseorang untuk hidup lebih sehat, lebih baik, tidak mudah depresi serta hubungan positif dengan orang lain (dalam Awaliyah dan Listyandini, 2017).

Adapun penelitian yang dilakukan oleh Ramel, Goldin, Carmona, dan McQuaid (dalam Mahmoudzadeh, Mohammadkhani, Dolatshahi, dan Moradi, 2015) pada siswa mendapatkan hasil bahwa mindfulness dapat meningkatkan psychological well-being yaitu dengan cara menurunkan pola pemikiran yang berulang juga melakukan penerimaan atas apa yang terjadi pada dirinya.

Hasil penelitian yang selaras lainnya ialah penelitian oleh Erpiana dan Fourinalistyawati (2018) pada dewasa awal dan penelitian oleh Savitri dan Listyandini (2017) pada remaja. Karena itu, jika individu bersikap sadar maka akan semakin mampu mendeteksi dirinya dari pikiran negatif.

Mindfulness menurut Kabat-Zinn (1994) adalah peningkatan kesadaran 
yang berfokus pada pengalaman sekarang serta penerimaan tanpa memberikan penilaian (dalam Thompson dan Gauntlett, 2008).

Baer, Smith, Hopkins, Krietemeyer, dan Toney (2006) menyatakan bahwa mindfulness adalah sebuah keadaan di mana individu sadar terhadap keadaan yang terjadi pada saat itu juga, serta tidak berpikir atau terfokus pada masa lalu maupun masa depannya melainkan fokus pada keadaan sekarang. Penelitian Bluth dan Blanton (2014) juga menjelaskan bahwa mindfulness menjadi salah satu yang dapat membantu remaja mencapai kesejahteraan dan kesehatan emosi (dalam Savitri dan Listiyandini, 2017).

Hal ini mengarahkan individu untuk lebih mengerti keadaan dirinya sehingga dapat mengeksplorasi diri lebih mendalam, menentukan apakah ingin menentang dan mengubah diri atau mengingatkan diri akan aspek positif dan kelebihan pada dirinya. Faktor lain yang mempengaruhi psychological well-being salah satunya adalah pemaafan dengan cara mengubah fikiran, emosi dan perilaku negatif kepada respon positif (Windi dan Marettih, 2018).

Faktor lain seperti happiness (Fadhillah, 2016), gratitude (Ratnayanti dan Wahyuningrum, 2016) serta resiliensi (Purwanti dan Kustanti, 2018) juga mempengaruhi psychological well-being.

Mindfulness sangat dibutuhkan oleh semua orang terkhusus remaja difabel untuk menerima kondisinya, mengembangkan dirinya untuk mencapai kesejahteraannya. Dengan ini peneliti tertarik untuk melakukan penelitian untuk menjawab pertanyaan bagaimana hubungan mindfulness dengan psychological well-being pada atlet remaja difabel.

\section{METODE PENELITIAN}

Penelitian ini menggunakan pendekatan kuantitatif. Populasi penelitian adalah 140 atlet remaja. Taraf kesalahan sebesar 5\% merujuk pada table penentuan jumlah sampel Isaac dan Michael, maka sampel penelitian berjumlah 100 atlet.

Penelitian ini menggunakan dua variabel, yaitu psychological well-being dan mindfulness. Penelitian ini menggunakan alat ukur Psychological Well-Being Scale (PWBS) sebanyak 36 butir pernyataan, dan Five Facet Mindfulness Questionnaire sebanyak 40 butir pernyataan.

Masing-masing skala berisi pernyataan dengan 4 pilihan jawaban. SS (Sangat Setuju), S (Setuju), TS (Tidak Setuju) dan STS (Sangat Tidak Setuju). Pelaksanaan penelitian selama 1 bulan secara offline ke tempat penelitian, dengan terlebih dahulu melakukan observasi dan wawancara dengan pengurus komite dan beberapa subjek. Try out terpakai digunakan karena ketersediaan subjek yang terbatas yaitu remaja difabel. Pengambilan data penelitian dilakukan sebanyak tiga kali.

Analisis data yang digunakan adalah teknik Pearson Product Moment Correlation, yaitu teknik yang digunakan untuk mengukur hubungan antara variabel independent dan variabel dependent (Arikunto, 2013) dengan bantuan SPSS Statistic 23 for windows. Sebelum melakukan analisa data perlu dilakukan uji asumsi, yaitu uji normalitas dan uji linearitas. 


\section{HASIL DAN PEMBAHASAN}

Responden penelitian ini sebanyak 100 atlet remaja difabel terdiri dari responden laki-laki sebanyak 51 responden dan responden perempuan sebanyak 49 responden. Oleh karena itu, pengolahan data menggunakan korelasi Pearson.

Tabel1: Uji Korelasi

\begin{tabular}{llll}
\hline Variabel & $\mathrm{R}$ & $\mathrm{P}$ & Ket. \\
\hline Psychological & 0,278 & 0,000 & Korelasi \\
Well-Being & & & lemah \\
Mindfulness & & & $(\mathrm{P}<0,05)$ \\
\hline
\end{tabular}

Berdasarkan hasil analisis diperoleh nilai Pearson Correlation sebesar 0.278 dengan Sig sebesar $0.005(\mathrm{p}<0.05)$. Hal ini menunjukkan adanya korelasi positif antara mindfulness dengan psychological well-being. Dari hasil ini, maka dapat dinyatakan bahwa hipotesis diterima.

Tabel 2: Sumbangan Efektif

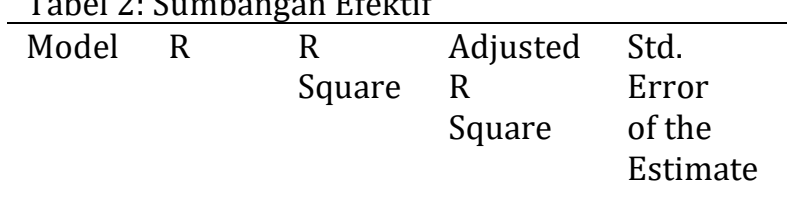

\begin{tabular}{lllll}
\hline 1 & $.278 \mathrm{a}$ & .077 & .068 & 1.33668
\end{tabular}

Berdasarkan tabel 2, tampak bahwa nilai $R$ Square $=0.077$. Dari nilai tersebut dapat disimpulkan bahwa mindfulness memberikan sumbangan efektif sebesar 0.77 persen terhadap psychological wellbeing dan sisanya 99.23 persen dipengaruhi oleh faktor lain yang tidak diteliti.

Seseorang yang memiliki mindfulness yang tinggi akan memiliki psychological well-being yang tinggi juga dalam kehidupan sehari-hari. Hal ini sejalan dengan hasil penelitian yang dilakukan oleh Istiqomah dan Salma (2019) yang menunjukkan bahwa mindfulness merupakan salah satu faktor yang berkorelasi positif dengan psychological well- being. Erpiana dan Fourianalistyawati (2018) juga menjelaskan bahwa empat dari lima dimensi yang terdapat pada mindfulness berperan terhadap setiap dimensi psychological well-being.

\section{SIMPULAN}

Berdasarkan hasil yang didapatkan dalam penelitian ini, dapat disimpulkan bahwa terdapat hubungan positif antara mindfulness dengan psychological wellbeing pada atlet remaja difabel di NPC Provinsi Sumatera Utara, dengan nilai koefisiein korelasi Pearson Product Moment $(\mathrm{r})=0,278$ dan $\mathrm{p}=0.000$ $(\mathrm{p}<0,05)$ yang artinya semakin tinggi mindfulness yang dimiliki atlet remaja difabel maka psychological well-being akan semakin tinggi dan sebaliknya jika semakin rendah mindfulness yang dimiliki atlet remaja difabel, maka psychological well-being akan semakin rendah.

Tingginya tingkat psychological wellbeing pada atlet remaja difabel turut dipengaruhi dari kompetensi yang dibekali oleh komite. Kompetensi ini diharapkan membantu atlet untuk lebih menyadari kemampuan dirinya, bertindak sesuai nilai dan minat sehingga atlet remaja mampu mengembangkan diri dan lebih mandiri lagi.

\section{DAFTAR PUSTAKA}

Arikunto, S. (2013). Prosedur Penelitian. Jakarta: Rineka Cipta.

Astuti, W., \& Marettih, A. K. (2018). Apakah Pemaafan Berkorelasi dengan Psychological Well-Being pada Remaja yang Tinggal di Panti Asuhan? Jurnal Ilmu Perilaku , 41-53. 
Awaliyah, A., \& Listiyandini, R. A. (2017). Pengaruh Rasa Kesadaran terhadap Kesejahteraan Psikologis pada Mahasiswa. Jurnal Psikogenesis , 89-101.

Baer, R., Smith, G. T., Hopkins, J., \& Krietemeyer, J. (2006). Using Self Report Assesment Methods to Explore Facets of Mindfulness. Assesment , 27-45.

Erpiana, A., \& Fourianalistyawati, E. (2018). Peran Trait Mindfulness terhadap Psychological Well-Being pada Dewasa Awal. Jurnal Psympatik , 67-82.

Fadhillah, E. P. (2016). Hubungan antara Psychological Well-Being dan Happiness pada Remaja di Pondok Pesantren. Jurnal Ilmiah Psikologi , 69-79.

Istiqomah, S., \& Salma. (2019). Hubungan antara Mindfulness dan Psychological Well-Being pada Mahasiswa Baru yang Tinggal di Pondok Pesantren X, Y, dan Z . Jurnal Empati , 127-132.

Jahja, Y. (2012). Psikologi Perkembangan. Jakarta: Kencana.

Mahmoudzadeh, S., Mohammadkhani, P., Dolatshahi, B., \& Moradi, S. (2015). Prediction of Psychological Well-Being based on Dispositional Mindfulness and Cognitive Emotion Regulation Strategies in Students. PCP , 195-202.

Purwanti, D. A., \& Kustanti, E. R. (2018). Hubungan antara Resiliensi dengan Psychological Well-Being pada Ibu yang memiliki Anak dengan Gangguan Autis. Jurnal Empati , 283-287.

Ratnayanti, T. L., \& Wahyuningrum, E. (2016). Hubungan antara Gratitude dengan Psychological Well-Being Ibu yang memiliki Anak Tuna Grahita di SLB Negeri Salatiga. Jurnal Satya Widya , 57-64.

Ryff, C. D., \& Keyes, C. L. (1995). The Structure of Psychological Well-Being Resivited. Journal of Personality and Social Psychology, 719727.

Savitri, W. C., \& Listiyandini, R. A. (2017). Mindfulness dan Kesejahteraan Psikologis pada Remaja . Jurnal Penelitian Psikologi, 43-59.

Senra, H., Oliveira, R. A., Leal, I., \& Vieira, C. (2011). Beyond the Body Image: A Qualitative Study on How Adults Experience Lower Limb Amputation. Clinical Rehabilition , 180-191.

Tasema, J. K. (2018). Psychological Well-Being dan Kepuasan Kerja pada Karyawan di Kantor X. Jurnal Maneksi , 39-46.
Thompson, M., \& Gauntlett-Gilbert, J. (2008). Mindfulness with Children and Adolescents: Effective Clinical Application. Clinical Child Psychology and Psychiatry, 395-407. 